\title{
Multiculturalism, Minority Rights and Democracy in India
}

\author{
Md. Ayub Mallick \\ Department of Political Science, University of Kalyani, Kalyani, Nadia - 741235
}

\begin{abstract}
The question of Indian unity has never been settled beyond all differences and disputations. We have no culturally homogeneous, dominant and majority ethnic and religious group that could both dominate as well as effectively claim to represent all Indians. Group rights act as the regulatory devices for the accommodation of differences. From egalitarian view of justice minority groups have a moral justification for demanding cultural rights, which is the structure for belongingness. Many liberals call for greater tolerance of minority groups. Indian democracy is not consociational, but has adopted consociational devices for dealing with diverse conflicts within society. It has sometimes proved possible for various political parties (multiethnic) to co-operate, form coalitions after elections and even before that and reach agreements on controversial matters affecting the cultural and group rights.

Key words: Consociationalism. Accommodation. Autonomy. Nation-building. Governmentality. Multiculturalism. Deliberative democracy.
\end{abstract}

\section{Multiculturalism, Minority Rights and Democracy in India}

Pluralism arises from the dynamics of the modernization process, which has enhanced multi-ethnicity and multiculturalism. In fact, differences of opinion and interest provide democracy its content and rationale. Multiculturalism is only one aspect of the problem, pluralism poses to liberal democracy. There are four options to solve these problems of pluralism - (1) solving of differences through neutral approach in liberal democracy, (2) solving of differences through negotiation, trading and compromise formula, (3) solving of differences through segregation of group rights and consociationalism, and (4) solving of differences through recognition of differences and accommodation of differences etc. It mixes voices and promotes deliberation, pooling of sovereignty, partnership and dispersal of power (Scott, 1998). It is compromise by negotiation. A functioning democracy requires a continuous process of discussion, resting ultimately on public opinion reached by discussion and the interplay of ideas.

Here, I do prefer consociationalism, where consociationalism and group rights attempt segregation, which give each group autonomy within its domain and a mutual veto. Negotiated agreements, which offer genuinely reciprocal compromises - are mutually acceptable and legitimate, fair and stable. Constitution is a form of accommodation of cultural diversity - an intercultural dialogue, when and where culturally diverse groups negotiate agreements in accordance with three conventions of mutual recognition, consent and cultural continuity. Amy Gutmann regards that - 'Recognizing and treating members of some groups as equals now seems to require public institutions to acknowledge rather than ignore cultural particularities, at least for those people whose self-understanding depends on the vitality of their culture. This requirement of political recognition of cultural particularity - extended to all individuals - is compatible with a form of universalism that counts the culture and cultural context valued by individuals as among their basic interests.' (Gutmann, 1994: 3). Cultural institutions should recognize the identities of cultural and disadvantaged minorities. Public institutions should justly respond to the strange multiplicity of culturally diverse voices, to inform constitutionalism where the demands are taken into consideration and adjudicated. Charles Taylor's philosophy, Michel Foucault's concept of genealogy and governmentality and Hannah Arendt's concepts of freedom and active citizenship provide immense importance to the philosophical discussion of multiculturalism. The constitution cannot eliminate or overcome the cultural dimension of politics. Cultures are interdependent and interactive, continuously contested, transformed and negotiated. Culture is the natural language of difference. ' $\ldots$ one of the basic values of our culture is that it and its basic values are relative, i.e., that it is one culture among many essentially unrelated cultures.' (McGrane, 1989: 120).

Multiculturalist perspective requires that each and every political community needs to provide autonomous spaces. The flexibility, autonomous and accommodative process of nation-building process helps the various communities, particularly the minority religious community, in identifying themselves with the 'nation'. The fact of minority rights enhances the legitimacy of the state and strengthens the cause of national integration, limits the processes of cultural assimilation and homogenization, and helps flexible and democratic institutional pluralism. 
Pluralism is an idea by which the diversity underlies the nationhood. Citizenship is a key institution by means of which competing demands for membership are made, an engagement between individuals, social groups and the state, and a method through which nationhood is achieved. Among the three citizenship approaches of liberal, republican and ethno-nationalist, I do prefer the last one, where the liberals argue for individuals as units and bearers of individual rights, republicans for common good and community as unit and ethno-nationalists for citizenship membership by descent group that defines the nation. Gandhian notion of nonstatist citizenship transcends ethno-nationalist citizenship - there is no majority victory over minority, all must deliberate together until unanimity is achieved. It may be mentioned here that economic liberalization has enhanced liberal citizenship discourse. The new liberal agenda in India, particularly the economic aspect of liberalization is partly a significant departure from Nehruvian model of social democracy and a continuation of modernizing goals through capitalist and liberal-democratic institutions. Despite the approach to 'good governance', deregulation, privatization and marketization have brought about changes in the notions of democracy, justice and welfare - these would remove decisions from the political arena and reduce political pressures on the state. However, the state would attempt to combine market efficiency with state welfarism. The nature of the welfare state in India facing necessarily two challenges - market demands and minimum state requirements and challenge from group members and demand for interventionist state. It may be mentioned here that the "politics of "collective personalities" - such as cohesive religious communities in search of identity or constellations or disadvantaged groups seeking empowerment - deny individuals what they claim for themselves and render the vocabulary of rights ineffectual, because it is individual-centered. The state, in turn, has failed in terms of its intolerance of class-based agitations, and its relative responsiveness to the demands of ethnic communities. It has also, in its withdrawal from welfare functions, rendered citizens vulnerable, and forced them to resort to support structures of kith and kin for material and emotional sustenance.' (Mahajan, Pai and Jayal, 1994: 116). In modern India politics of cultural difference has been of pre-eminent value. The question of Indian unity has never been settled beyond all differences and disputations. We have no culturally homogeneous, dominant and majority ethnic and religious group that could both dominate as well as effectively claim to represent all Indians. However, the Hindu extremist party, like BJP is trying to develop one homogeneous nation-state denying the heterogeneity. '.. the concept of multiculturalism can prove to be an effective counter to the homogenizing project of hindutva and there exists, on account of this very reason, a strong case for its promotion and encouragement in this country.' (Ali, 2000: 2503).

'One nation, one culture, one people' has its origin in post-renaissance European thought. Western liberalism is concerned with individual rights, but communitarians are concerned with group rights. Group rights are concerned with cultural membership and cultural rights. Group rights act as the regulatory devices for the accommodation of differences. From egalitarian view of justice minority groups have a moral justification for demanding cultural rights, which is the structure for belongingness. Many liberals call for greater tolerance of minority groups. Leftist intellectuals modify Rawls's idea of a rational agreement and substantial common good and try to infuse a more self-consciously political life. It is very difficult to distinguish 'public' and 'private' good. Mouffe's idea is more self-consciously political life. Pluralism is possible on the condition of self-consciously political life and a minimum shared agreement. Common political good can be achieved through the principles of liberty and equality of liberal-democratic regime 'qua political association'. Morality and religion as 'private' beliefs and sphere of 'privacy' cannot intervene the 'public' sphere of political institutions embodying the political principles of equality and liberty. ' . . a liberal-democratic regime, if it must be agnostic in terms of morality and religion, cannot be agnostic concerning political values...' (Mouffe, 1990: 223). Dipesh Chakraborty argues that - '... critics of these institutions, whether arguing from a purely liberal position of a Rawls or a postmodernist, socialist position of a Mouffe, cannot but resurrect the model of a human being who holds on to a cultural distinction between the public and the private, as a condition for tolerance and pluralism... one is to document and interpret for contemporary needs the different practices of toleration and pluralism that already exist in Indian society, practices that are not critically dependent on the universalization of the public/private distinction. The other would to help develop critiques of the already existing institutions and their theoretical assumptions, for the struggle against the murderous and self-proclaimed 'Hindus' of today must, in the long run, also be a struggle for new kinds of political and economic institutions for the management of public life...' (Chakraborty, 1995: 3379). Gurpreet Mahajan asserts that the Indian constitution has devised a 'two-fold' policy - non-exclusion of the disadvantaged minority in the public sphere and autonomy to religious community to pursue their way of life in the private sphere. The 'aspects of the liberal ethic have been incorporated into community practices and as a consequence, in these liberal societies, community rights have not been frequently conflicted with the principle of gender equality.' (Mahajan, 1998: 7). She regards that uniform civil code has prescribed 'the limits of permissible cultural diversity'. The demand of the religious communities for personal laws is justiciable from their own point of view of cultural and group rights.

The reality of multiculturalism challenges the concept of 'one nation, one culture, one people' and the concept of majoritarian rule. Group and cultural rights are related with or can be attained with the help of 
regional autonomy, proportional representation in legislative assemblies, reservations in education and employment, language rights, equal participation of all citizens within the national polity and choice of national symbols. Majoritarian democracy does not require group rights and regards individual rights, are adequate to protect group rights. Classical liberalism believes in the rights of the individuals and finds 'right to culture' as problematic. Bhargava recognizes that 'a right to culture is believed to be a collective entity but for liberals collective rights cannot exist. This flows from the liberal commitment to individualism, to the view that only the individual defined in abstraction from other individuals is the final source of moral and cognitive authority and therefore he alone is the ultimate unit of moral worth... A second argument also stems from the liberal tie to atomism... Rights of culture, so the argument goes, are always used to restrict or violate individual rights. Therefore they cannot be accommodated within a liberal framework.' (Bhargava, 1991: 165-72). Culture of rights means the existence of differences and settlement of these differences peacefully and through reason. In fact, right to culture depends on culture of rights.

Democracy can deliver justice to all its citizens. Neera Chandhoke regards that - 'Whereas democracy has been used to defend the right to property in the name of freedom, it has been equally used to critique the institution of private property from the standpoint of equality or, democracy has been conceptualized as majority rule, as well as a protection against majority rule. Democracy has been interpreted as elitist or as pluralist democracy, participative, institutional or substantive democracy, or as egalitarian democracy. The way we interpret it, therefore, depends on the nature of the conceptual web in which we place democracy and the way we justify it.' (Chandhoke, 1999: 123). Democracy will reduce the minimization of differences. The task here is to acknowledge the fact and fluidity of differences. The ineliminability of differences couples with the recognition of specific differences. Human rights or minority rights are regulatory devices for the accommodation of differences. The need is vibrant democracy with procedural and substantive justice and active participation of citizens other than Rawlsian procedural justice and Habermasian force of better argument. Liberals on the question of secularism regard maximum individual autonomy by providing neutrality on the part of the state. Communitarians prefer perfectionism rather than that of state neutrality - the conception of good life and peace. Toleration of differences is more concerned with the promotion of peace between various groups. Bhiku Parekh's 'respect-based liberalism is wider and is more acceptable than that of 'tolerance-based liberalism'. The concept of cultural membership enhances self-esteem of John Rawls and Charles Taylor's struggle for recognition. It is politics of recognition that is simultaneously suspicious of all social differentiations and receptive to the homogenizing... tendencies of a politics of the common good,...' (Gutmann, 1994: xi). Taylor is concerned more with recognition for one's particularity. It is political recognition of the distinctive contributions and qualities of minority cultures are most often viewed as a way of treating members of those cultures as equals. 'Liberals like Rawls and Dworkin call for an ethically neutral legal order that is supposed to assure everyone equal opportunity to pursue his or her own conception of the good. In contrast, communitarians like Taylor and Walzer dispute the ethical neutrality of the law and thus can expect the constitutional state, if need be, actively to advance specific conceptions of the good life.' (Gutmann, 1994: 111). 'The problem here is that we must decide between the ideal of peaceful coexistence and the imperatives of justice, and between the politics of identity and those of reform... Whereas change and reform are allowed by Parekh only from within the group itself, Kymlicka's claim is that the moral and cultural frontiers of a group do not necessarily coincide... Kymlicka is aware of the multiple, sometimes hybrid, voices within a group, that he is concerned about the voices of discontent - those raising the demand for autonomy - within minority groups. Parekh's respect-based liberalism values our socio-cultural associations, but is apparently unconcerned about conflicts within these groups. Mutual respect between different communities could end up privileging the hegemonic expression of patriarchal and other elite sub-groups within cultural communities.' (Rajan, 2002: 131).

Indian nation-state has adopted Western parliamentary set up with liberal-democratic character. The nation-state is defined in terms of territorial political community of citizens. Nation-building process in India is associated with state-sponsored and state-directed process of economic development and social transformation. The 'concept of nation building has been challenged... Infused with a strong missionary zeal of unitary nationalism Hindutva seeks to legitimize majority communalism in the name of nationalism. Such an ideology of nationalism, i.e. majority-ethnicism, cannot serve as the basis for the functioning of a modern state in India a multiethnic society.' (Seth, 1999: 35). In India, we find a contradiction between civil society and political national society and minority rights in terms of citizenship rights, are insufficient to protect cultural identity of the minority communities. In liberal democracy fairness demands more than state neutrality and considerations of justice, freedom, citizenship and equality demand differences of cultural identities, cultural and group rights, multiculturalism, the claims of diversity, politics of difference and recognition. Public institutions should recognize cultural and disadvantaged minorities. 'This requirement of political recognition of cultural particularity - extended to all individuals - is compatible with form of universalism...' (Gutmann, 1994: 3). Culture is marked with marginalization and politics of redress of grievances. Multicultural perspective is 
concerned with justice, fairness and citizenship. Constitution is a 'form of accommodation of cultural diversity' and 'an intercultural dialogue in which the culturally diverse sovereign citizens of contemporary societies negotiate agreements.' (Tully, 1995: 30). It is essential to justify multiplicity of culturally diverse voices. Wittgenstein's idea of language game, Michel Foucault's genealogy and governmentality, and Hanna Arendt's concept of freedom and active citizenship are sources of multicultural tradition. Politics of cultural recognition means gathering the broad and various political activities which jointly call cultural diversity into question as constitutional problem. 'A constitution can seek to impose one cultural practice, one way of rule following, or it can recognize a diversity of cultural ways of being a citizen, but it cannot eliminate, overcome or transcend this cultural dimension of politics.' (Tully, 1995: 6). In fact, cultures are overlapping, interactive and internally negotiated. Culture is the universal and commanding natural language of difference. All the differences are fundamentally relative. ' $\ldots$ one of the basic values of our culture is that it and its basic values are relative, i.e. that it is one culture among many essentially unrelated cultures... knows that it is relative, ... it locates its own superiority in this knowledge of its relativity, as it likewise locates inferiority in ignorance of this relativity.' (McGrane, 1989: 120). Taylor (1992) finds that politics of equal recognition is important and fundamentally human life is dialogical and interactive. As human agents we define our identity. We are interacting with significant others. Human identity rests on autonomy, on the ability of each person to determine the good of life. In 'politics of equal identity, what is established is meant to be universally the same, an identical basket of rights and immunities... forms of non-discrimination that is quite "blind" to the ways in which citizens differ.' (Taylor, 1992: 38-39).

Minority protection has fallen in the private domain. But there is less emphasis on equal recognition to minority groups in the public sphere. The public sphere in India is not sensitive to diversity and cultural plurality of this country. On $30^{\text {th }}$ December, 1948 Sardar Patel observed that members of the Advisory Committee of the Constituent Assembly felt that - ' $\ldots$ conditions having vastly changed since the Advisory Committee made their recommendations in 1947, it was no longer appropriate in the context of free India and of present conditions that there should be reservation of seats for Muslims, Christians, Sikhs or any other religious minority.' (CAD, Vol. III: 311). On $25^{\text {th }}$ May, 1949 Sardar Patel observed that time has come when the vast majority of the minority communities have realized that the reservation should be dropped. Ansari (1999) says that the Chairman of the Sub-Committee on Minorities, H.C. Mookerji and Tajmal Hussain played a key role in supporting the ideal of pure homogenized nationhood. 'The compulsions of the pursuit of undiluted pure nationalism made further demands on whatever little was left intact by way of assuring minorities, in terms of due consideration to their claims in public services, though qualified by of efficiency of administration... When the assembly met on $14^{\text {th }}$ October, 1949 it was presented with a changed text of Articles 296 and 299 deleting 'minorities',... All amendments seeking guarantee of minorities share in public services were, however, defeated.' (Ansari, 1999: 123). Furthermore, the Indian state and polity are not interested to encroach upon the private sphere of the religious minority communities, for example the Shah Bano controversy case, where the Muslim orthodox section resented their voices against the encroachment of their private sphere. A graphical representation may be sketched below:

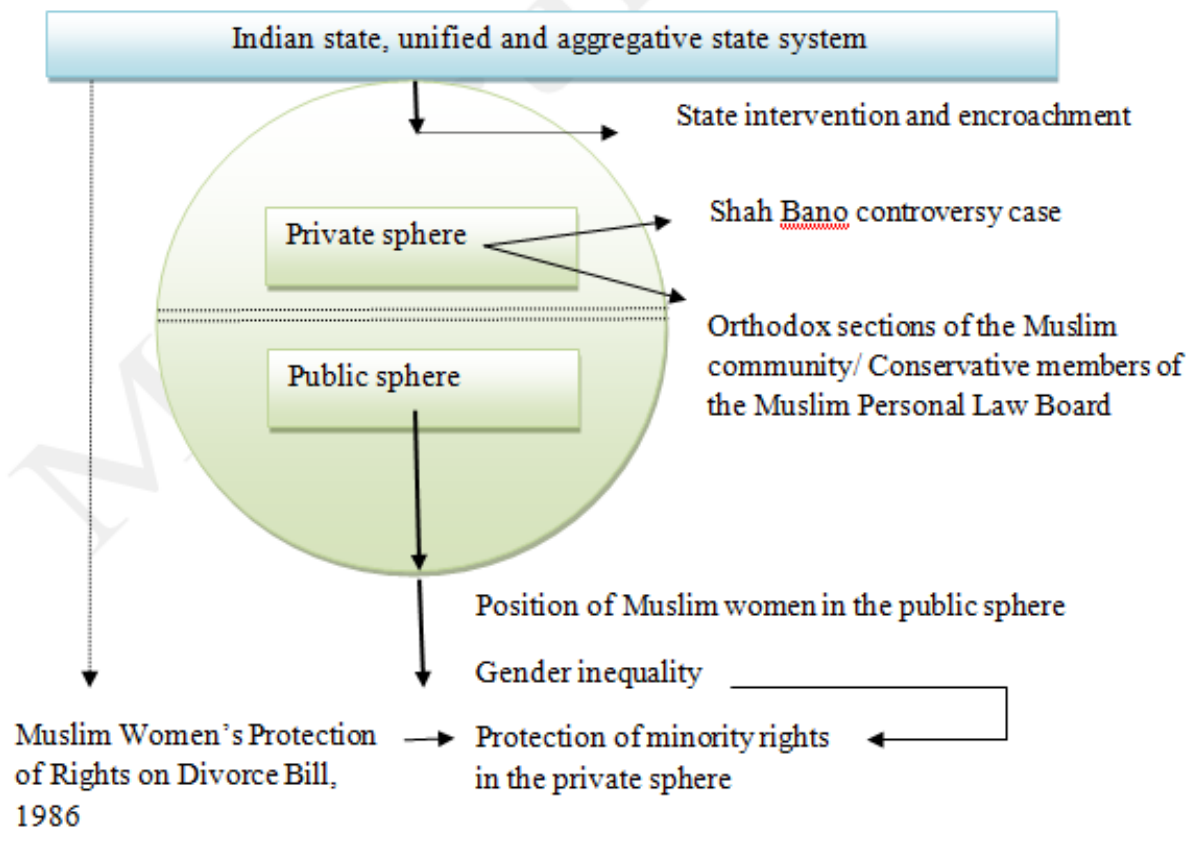


Gender equality in Shah Bano case was subordinated to religious claims and religious membership and gender equality came into conflicts with religious claims of a minority group. In Danial Latifi case the Supreme Court in its judgement recognized the diversity of traditions. In Shah Bano and Danial Latifi cases the Supreme Court attempted to ensure equal respect and treatment for Muslim women, regardless of religious membership and diversity of traditions. The question is to resolve the conflict between gender equality and religious cultural claims, to reforming the religious-cultural traditions. Deliberative democracy based on multiculturalism so to say can reconcile the conflict between gender equality and religious cultural claims. Cross-cultural dialogue is essential in this respect. It is the alternative ways of negotiating with conflicting claims. Cultural conflicts are rooted in a cosmopolitan point of view, from which negotiation of difference is both pragmatic and moral imperative. In this resolution of conflicts Benhabib (1992, 1995 and 2002) relies on dialectical process of reasoning and universal and necessary presuppositions of communicative speech. Within the limits of reasonable pluralism conflicting cultural claims can be negotiated and resolved. Benhabib (1992) makes a multicultural arrangement. Three key principles are necessary for this multicultural arrangement - egalitarian reciprocity, voluntary self-ascription and freedom of exist and association. For a just multicultural arrangement the freedom to exist and to disassociate from the group must be unrestricted, which communitarians like Bikhu Parekh does not believe and specify culture as a matter of non-preference and cultural membership as mandatory. Critics find that Benhabib does not find the role of culture put forwarded by communitarian multiculturalists. Kymlika puts forward his conception of multicultural citizenship based on respect-based liberalism. Benhabib's model of deliberative democracy and unrestricted freedom to exist and to disassociate may challenge the cultural "ways of life" of different cultural groups and cultural membership. Benhabib's voluntary self-ascription recognizes individual self-ascription and determination with group membership. She goes beyond mere legal regulation of conflicting cultural claims of communitarian multiculturalism and democratic equality. A combination of legal regulation and constitutional enforcement with expanded crosscultural moral-political dialogue allows sub-altern and subordinated voices within religious minority groups to be expressed and given proper weightage. Benhabib's approach is different from Shachar's 'joint governance' model recognizes the importance of legal regulation. 'The strategies adopted by the Indian Supreme Court provide us with valuable lessons on the cultural mediation of human rights norms... the Supreme Court chose to listen to sub-altern voices,... Those voices, though often appealing to background cultural justifications to support their claims, accepted Muslim women's right to be treated as equal citizens. A commitment to the constitutional essential of equality was the starting point for the Supreme Court's judgement in the Latifi case. In the Shah Bano case, it was the generally applicable law, the Code of Criminal Procedure and the societal obligation to ensure that Muslim women were not vulnerable to destitution and poverty as a result of a discriminatory application of the law. In both of these cases, we see an attempt to combine legal regulation with an expanded moral-political dialogue on the meaning and scope of constitutional essentials and religion-based personal laws.' (Mullally, 2004: 689).

Another aspect is national symbols and anthem. In fact, '... the various national symbols that have defined the public sphere have invariably acquired a majoritarian tinge, making it difficult for the minorities to identify with them. In any attempt to place multiculturalism on the agenda in this country, it is the aspect of making the public sphere more conducive to the expression of cultural diversity and difference...' (Ali, 2000: 2503).

Diverse social groups can find an important place by negotiating and balancing overlapping conceptions for competing membership claims without sacrificing various group identities. In India ethnonationalist citizenship discourse gained currency after partition. Indian constitution established a common citizenship based on individual rights and collectivist notion of citizenship and common good. In 1950s and 1960s Government failed to provide equal citizenship to the Muslims. There is a liberal dilemma in the role of the state with respect to religious community - 'If the government defers to the wishes of the religious group, a vulnerable groups of individuals will lose basic rights; if the government commits itself to respecting the equal human rights of all individuals, it will stand accused of indifference to the liberty of conscience.' (Nussbaum, 1999: 84). By the mid-1970s the republican conception of citizenship was called into question by non-statist citizenship discourse. During the emergency period an attempt was made by the Indira Gandhi government to restore republican discourse of citizenship by achieving socio-economic revolution, reducing poverty and ignorance. During this period a fundamental shift began to take place - growing prominence of ethno-nationalist and liberal citizenship discourses were balanced against each other. However, the process of economic liberalization from the 1980s provided the liberal citizenship discourse. Hindu nationalist discourse began popularity in response to ethno-nationalist discourse of citizenship. In India the minority incorporates not only the Muslims, but also the Christians, SCs, STs and OBCs etc. Therefore, the Muslim citizenship in terms of 'majority-minority' question cannot be constructed. 'Caste, tribal, linguistic as well as religious groups can be self-defined minorities for any one of a number of reasons: they have a distinctive group identity that they fear is eroding; they regard themselves as socially and economically subordinate to others; or they believe that they 
suffer from discrimination, either from others in the society or from the state itself... To declare one's group a minority is, therefore, a political act. In the Indian context, it is a way of calling attention to a situation of selfdefined deprivation... The term 'minority' has come to be reserved for those who are "disadvantaged".' (Weiner, 1989: 42-43).

Following the Hindu nationalist discourse Baxter (1969) points out Rashtriya Swayamsevak Sangh (RSS)'s version of Hindu nationalism that the non-Hindu peoples in India must adopt Hindu culture, must learn to respect Hindu religion, must cease to become foreigners and may stay in this land 'wholly subordinated to the Hindu nation, claiming nothing, deserving no privilege, far less any preferential treatment - not even citizens' rights'. (Baxter, 1969: 31). Minorities must reconcile with the majority Hindu domination. Articles 30 and 30(1) essentially permit concessions to the minorities that go against the spirit of Hindu state. Rajni Kothari (1986) rightly says that being afraid of losing their dominant and privileged position the Hindu middle classes have taken to Hindu nationalism. Indian leaders have adopted the concept of democracy or so to say market concept of democracy with a majoritarian tinge. It is the market democracy where the voters are treated as consumers with multifarious demands and politicians or leaders as entrepreneurs to bag their votes. Therefore, normative restraints are lacking in owning power. Further, Hindu religion is diffused and fragmented, so it is not possible to develop a unified nationalist ideology based on Hinduism.

David Washbrook finds that - in India 'in the 1950s Milton Singer attempted an explication through the concept of 'compartmentalization'. But not only does this challenge the theory of modernization itself... The specific tradition to which Singer referred was Brahmanic Hinduism... In the 1960s, Suzanne and Lloyd Rudolph tried to clarify the issue with their concept of 'the Modernity of tradition.' ... In the 1970s, Stephen and Marguerite Barnett attempted their own formulation. Noting the highly competitive nature..., with... pressures for social mobility,... that competition came to be mediated through the categories of caste, they offered the concept of 'collective individualism'... From the 1980s, the waning influence of Parsonian and neo-Weberian sociology meant that few scholars continued to try to understand southern in these terms. However, the debate revived again in the 1990s with the post-colonial turn... Modernity now became seen as an oppressive, dehumanizing discourse,...' (Washbrook, 2010: 128-129). In this context the question of minority rights is important, which may not be actually realized in a multi-cultural settings like India with an ideal-typical set of qualities consisting of tendencies towards individualism and rejection of collective rights or group rights, universalism and the recognition of the qualities of subjects, rationality, progressiveness and improvement of human conditions etc. An accommodative process of nation-building is necessary for the minority groups in identifying themselves with the nation, in limiting the homogenization process by the nation-state, in tackling the cultural hegemony of religious minorities and aggressive secularism, and in sharing the advantages of democratic institutional pluralism.

Considering group rights and diversity in Indian society the framers of the Indian constitution pointed out the following guidelines - freedom of conscience and religion, non-discrimination on grounds of religion by the state, no communal electorates, social welfare and reform, right to establish and run institutions for religious and charitable purposes, rights of religious minorities to establish and administer educational institutions, nondiscrimination on the grounds of religion for employment etc. Indian constitution accepts the liberal-secular framework of freedom, equality and fraternity, for example Articles 25 and 26 stating freedom of conscience and right to profess religion. However, secularism, nation-building and development as the core legitimizing concepts help the Indian state leaders 'to legitimize themselves as the sole arbiters among traditional communities, to claim for themselves a monopoly on religious and ethnic tolerance and on political rationality.' (Nandy, 1988: 192). Here, religion is treated as politically constructed monolithic, communalist ideologies of sectarianism and intolerance. Secularist ideology is not an adequate political perspective for meeting the challenge of Hindu majoritarianism. Following Ashis Nandy's religious tolerance Partha Chatterjee (1994) calls for political tolerance as a part of non-Western form of modernity. There should be a proper relationship between state and religious, ethnic and cultural groups and a framework beyond state sovereignty versus individual rights discourse of liberalism. Likewise Foucault, he maintains that modern form of power is not concentrated within a single whole, cuts across the liberal division between state and civil society and is exercised through various forms of representation and methods and technologies of governmentality. It is argued that 'there will be political contexts where a group could insist on its right... toleration here would be premised on autonomy and respect for persons,...' (Chatterjee, 1994: 1775). Religious, cultural and ethnic communities are institutional sites or strategic locations of the politics of identity and difference. To Chatterjee, 'if a religious group declares that the validity of its practices can only be discussed and judged in its own forums, those institutions must have the same degree of publicity and representativeness that is demanded of all public institutions having regulatory functions.' (Chatterjee, 1994: 1775).

Power in modern society is pervasive. Civil society has emerged as the central player in championing the cause of the minority communities against the power of Hindu majoritarianism. Strong and active civil society in India is characterized by heterogeneity and representation of multiple ideologies. Though the civil 
society organizations have different ideological positions, they have a common starting point - constitutional guarantees providing few rights to the minority communities. There is a closer relationship between socioeconomic deprivation and religious, cultural and ethnic identity. Barbara Harriss White (2002) and Justino and Litchfield (2003) find the implications of religious plurality on capitalist economy and in shaping the economic capabilities and of relative deprivation and discrimination that contribute to the socio-economic exclusion of the minority communities. Hasan (2003) tries to find out that constitutional guarantees for religious and cultural rights of minorities have proved not proper in protecting minorities from discrimination. Failure to develop socio-economic development of the minorities by the Indian state is equal to discrimination. Political analysts must recognize that in a country which is characterized by glaring inequalities, appaling poverty, a highly vitiated social and political climate, wherein traditional loyalties are critical and where the political system has encouraged the jockeying for power caste by caste and community by community, the political secularization of minority communities cannot take place at a rate faster than that of the whole society. The whole society must grow and change at an even pace, and that is the only course for the successful socio-political integration of an otherwise diverse and plural society.' (Ahmed, 1971:26). With minority politics the emphasis is on inclusive citizenship and with majority politics, the emphasis is on exclusivity as a people. The conflict is between majoritarianism and minoritarianism. The conflict is between citizens and people. People mean aggregation of citizens under nationalism. In liberal democracy citizens take precedence over people and thus a nation-state faces two options - liberal-democratic and nationalist. In liberal democracy citizens as individuals have rights, which are inviolable. Citizenship becomes a viable project when the enforcement of law respects the individual as a citizen and it does not make concessions to the sentiments of the 'people'. 'There are,..., two possible scenarious in the contemporary nation-state by which religion and politics can come together. The first arises from minority anxieties about their self-respect and their consequent demands for cultural equality. The second arises from majoritarian attacks on religious minorities in the name of protecting the nation-state from enemies within.' (Gupta, 2007: 31). Myron Weiner (1968) says that whether the minority group is a tribe or a religious or linguistic group, it is often concerned with preserving its cultural identity and resisting assimilation into larger regional and national culture. Minorities are even more protective. Narendra Subramanian (1999) finds that India's success in maintaining democracy in the midst of deep ethnic cleavages was ascribed to the accommodation of ethnic demands. Accommodative institutions eroded in the 1980s and 1990s and alternative secular pan-Indian nationalism grew its popularity. Hindu revivalism opposes official commitments to secularism, Sikh movement opposes pan-Indian nationalism, Kashmiri nationalism is secular but ambivalent about being part of India, and the Dravidian movement opposes pan-Indian, but accepts federalism. Organizational pluralism assists social pluralism and tolerance of difference within organizations enhances social tolerance among the members. Negotiation of differences builds an institutional culture to negotiate and compromise with other political forces. Social pluralism does not preclude the growth of non-pluralistic parties and movements.

To solve the problems of minorities the federal theory must self-consciously engage more thoroughly. The need is to develop the cosmopolitan model of democracy, which would delimit the form and scope of individual and collective action within the organizations and associations of state and civil society. Few standards are specified for treatment of all, which no political or civil association can legitimately violate (Held, 1994). Paul R. Brass (1974) calls for multi-ethnic and multinational state formation, where many nations bound together in a single political and territorial unit by feelings of patriotism derived from ideology, memories of a common struggle against external or alien powers, and rational calculations of common advantage in the sharing of a single political structure, but not by a common nationality.

It is argued that a fully-developed consociational model of democracy, whose specific characteristics are 'government by a grand coalition', 'the mutual veto or "concurrent majority" rule', 'proportionality in recruitment to decision making bodies and public services and in allocation of public funds', and 'a high degree of autonomy' (Lijphart, 1977: 215), is inherently undemocratic and violates rights of unrecognized groups and also rights of the individuals. But the four principles would produce viable opposition to majority dominance and make plural societies more plural. Against Barry's (1975) argument that ethnic divisions are more inflammatory and less negotiable than that of religious and class groups Lijphart (1977) argues that ethnic divisions and divisions based on religion and class are matters of degree, not of kind. The divisions and conflicts of all kinds can be solved through consociationalism. I do agree with this. Unlike Barry, Berghe (1981) agrees with the usefulness of consociationalism for ethnically divided societies to preserve unitary multiethnic state rather than permit the state to breakdown into ethnic components. Berghe and Lijphart agree that there are only systems of democracy and domination, when liberal democracy is simply a tyranny of the majority. India is both a society of pluralism and society of conflicts and divisions. Indian democracy is not consociational, but has adopted consociational devices for dealing with diverse conflicts within society. It has sometimes proved possible for various political parties (multiethnic) to co-operate, form coalitions after elections and even before that and reach agreements on controversial matters affecting the cultural and group rights. But this has not 
proved fruitful in India in practice. Consociationalism rather than political accommodation is a solution to this problem. 'When one ethnic group is blatantly discriminating against or oppressing another, it is nothing but an analytical distraction to propose a consociational remedy.' (Brass, 1991: 345). But I do propose consociational model, has a much better chance than majoritarian democracy, which is more subject to failure in plural societies. The more plural the society, the more important it is to keep the possibility of change, division and secularization for the integration of people in a common political order and to preserve individual and group rights with a individual and group autonomy. However, apart from segmental isolation I do agree that there is a closer relationship between social cleavages and political parties. There is the need for co-operation among various elites. 'Elites who seek to gain control over the state or who have succeeded in doing so must either suppress and control central and local rivals or establish collaborative alliances with other elites. When elites in conflict lack the bureaucratic apparatus or the instruments of violence to compete effectively, they will use symbolic resources in the struggle. When elites in conflict came from different cultural, linguistic, or religious groups, the symbolic resources used will emphasize those differences.' (Brass, 1991: 275).

Political culture and social structure are essentially inter-related. In multi-ethnic, multi-cultural, plural societies political culture is differentiated and fragmented. Overlapping membership and cross-cutting loyalties with diverse interests and outlooks lead to moderate attitudes and outlooks. Political stability needs moderation, seeks overlapping membership. ' ... a complex society may experience revolution, degeneration and decay. If it maintains its stability, however, it may do so in large measure because of the fact of multiple memberships.' (Truman, 1951: 508, 511), and because of 'criss-cross groups in action' (Bentley, 1955: 208). ' $\ldots$ the chances for stable democracy are enhanced to the extent that groups and individuals have a number of cross-cutting, politically relevant affiliations.' (Lipset, 1960: 88-89). Cross-pressures and overlapping pattern of membership are important. Not only political culture and role structures, but the behavior of political elites is important for the success of consociational democracy. Politics of accommodation and co-operation, grand coalition and cartel of elites are essential for stabilization of the system of consociationalism, which violates the principle of majority rule, but does not deviate from normative democratic theory. Consociationalism is based on 'size principle' of William H. Riker that in social situations similar to n-person zero-sum games with side payments, participants create coalitions just as large as they believe will ensure winning and minimum willing coalition, but only under the conditions specified in the size principle - only the direct conflicts among participants are included and common advantages are ignored. The zero-sum condition and the size principle apply only to societies with completely homogeneous political cultures and to societies with completely fragmented cultures. Political cultures deviate from these two extreme conditions, pressures will exist to fashion coalitions and that may be all-inclusive grand coalitions. An inter-elite accommodation becomes necessary in a fragmented system where there is the existence of external threats, multiple balances of power among the subcultures and a relatively low total load on the decision-making apparatus. To safeguard political stability contacts or communications must not exceed the commensurate degree of homogeneity. Stability depends on a balance between transaction and integration as the number of opportunities for possible violent conflict will increase the volume and range of mutual transactions. Transactions among antagonistic subcultures must be a minimum in a multinational state. Lijphart favours consociationalism than that of federalism although both are nonmajoritarian democracy. To him, there are two primary conditions and two secondary conditions of consociationalism - grand coalition and segmental autonomy as primary conditions and proportionality and minority veto as secondary conditions. Federalism can be defined in terms of division of power as primary condition and written constitution, bicameralism, overrepresentation of the smaller component units, right of the component units to be involved in the process of amending the federal constitution, and decentralized governance as secondary conditions. However, there is a closer relationship between consociationalism and federalism - federation qualifies consociation and consociation can also be a federation (Lijphart, 1979). Graphically, it may be presented as below: 


\section{If, Consociationalism $\bigcap$ denotes}

1) Segmental autonomy on a territorial-federal basis

2) Homogeneity with regard to segmental composition

3) Division of power

4) Written constitution

5) Bicameralism

6) Proportionality and minority overrepresentation

7) Right of the component units to be involved in the process of amending the federal constitution and to change their own constitutions

8) Decentralized governance

\begin{tabular}{|c|c|c|c|c|c|}
\hline B & C & D & $\mathbf{E}$ & $\mathbf{F}$ & G \\
\hline
\end{tabular}

\section{If, Federalism denotes}

1) Federations must be democratic

2) Federations can be consociations

3) Grand coalitions and segmental autonomy as primary conditions

4) Proportionality principle and minority veto as secondary conditions

5) Federations can be consociations with highly decentralized and highly autonomous component units

6) Approximation of segmental boundaries - heterogeneity is transformed into homogeneity

7) Relatively many and relatively small component units

then, it is Consociationalism with necessary conditions

(Note: $\mathrm{A}=$ executive power sharing, $\mathrm{B}=$ balanced executive-legislative relations, $\mathrm{C}=$ strong bicameralism, $\mathrm{D}=$ multi-party system, $\mathrm{E}=$ multi-dimensional party system based for example, on language, religion and ethnicity, $\mathrm{F}=$ proportional representation, $\mathrm{G}=$ federalism and decentralization, and $\mathrm{H}=$ written constitution and minority veto)

The Indian puzzle is even more troublesome for consociational power-sharing. Two important puzzles are posed by Indian democracy - survival of Indian democracy in spite of poverty and illiteracy which negates the correlation between socio-economic development and stable democracy (Dahl, 1989) and the Indian paradox of a more puzzling contradiction between high level of political violence and success of Indian democratic political system (Weiner, 1989). In plural society like India consociational democracy is best suited - this argument which I agree with Lijphart, is against the views of Mill (1958) and Harrison (1960) that democracy is next to impossible in multiethnic and linguistically divided societies like India and 'the odds are almost wholly against the survival of freedom and... the issue is, in fact, whether any Indian state can survive at all.' (Harrison, 1960: 338). Though Paul R. Brass regards that the consociationalists ignore the experience of India, the largest culturally diverse society in the world, which has functioned with a highly competitive system of politics (Brass, 1991), but India is not completely majoritarian. Rajni Kothari's description of Indian political system as a 'coalitional arena' (Kothari, 1970: 421), is close to grand coalition. The arguments put forwarded by Brass are relatively mild. The Indian variant of grand coalition is cabinet. Kothari (1989) presents that Indian democracy is a consensus system, which operates itself by and through the institution of a party of consensus. In fact, Lijphart's theory of consociational democracy has application to the Indian integration pattern. Indian political elites are committed to reconciling differences through bargaining amongst themselves (Young, 1976). Language in India has produced integrating influence. Few important ground factors of power-sharing are favourable in India and hence, consociational democracy has been established in India. Firstly, India's Hindu 
majority is internally divided to such an extent that the country consists of minorities. Secondly, there are largescale disparities in India among linguistic and religious groups. Thirdly, too many disparities and divisions create negotiations among diverse groups difficult. Fourthly, without any clearly dominant groups, the minority groups achieve a rough balance of power. Fifthly, Weiner regards that 'India's success in sustaining democracy despite growing tensions and violence can be explained, first, in terms of its federal system... and second, in terms of the size of the country, which means that much of the conflict remains localized and does not directly endanger the central authority. Weiner's second argument... suggests that the relationship between size and the chances for power sharing is curvilinear...; as size increases, conditions for power sharing worsen initially,...' (Lijphart, 1996: 263). Sixthly, external danger promotes national unity and reduces particularistic loyalties. Seventhly, geographical concentration of linguistic minorities promotes linguistic federalism. Eighthly, traditions of accommodation and compromise promote consociationalism. I fact, consensus has deep roots in Indian decision-making process. Indian conditions are favourable to power sharing. Conflict management in India has become more difficult with the decline of Congress organization and the weakening of federal structure with the centralization of power in post-Nehru leadership, mass mobilization and activation, decline of Congress party's electoral strength, attack on minority rights and rise of militant Hindu nationalism. Consociationalism will reduce group conflicts. Concessions to group power and preferences will be reinforced with this process of consociation. Nordlinger's 'conflict-regulating' practices are associated with consociationalism, though Nordlinger excludes federalism from the power sharing process.

11. Ahmed, Imtiaz. 1971. 'Secularization', Seminar (Vol. 144)

[2]. Ali, Amir. 2000. 'Case for Multiculturalism', EPW (Vol. 35: Nos. 28-29).

[3]. Ansari, Iqbal A. 1999. 'Minorities and the Politics of Constitution Making in India' in D.L. Seth and G. Mahajan (eds.), Minority Identities and the Nation-State (New Delhi: Oxford University Press).

[4]. Barbara, Harriss White. 2002. 'India's Religious Pluralism and its Implications for the Economy', Working Paper No.82 (Oxford: Oxford University Press).

[5]. Barry, Brian. 1975. 'Political Accommodation and Consociational Demecracy', British Journal of Political Science (Vol. 5).

[6]. Baxter, Craig. 1969. The Jana Sangh (Philadelphia: University of Pennsylvania Press).

[7]. Benhabib, Seyla. 2002. The Claims of Culture (Princeton: Princeton University Press).

[8]. Benhabib, Seyla. 1992. Situating the Self Gender, Community and Postmodernism in Contemporary Ethics (Cambridge: Polity Press).

[9]. Benhabib, Seyla. 1995. 'Cultural Complexity, Moral Intredependence, and the Global Dialogical Community' in M. Nussbaum and J. Glover (eds.), Women, Culture and Development (Oxford: Clarendon Press).

[10]. Bentley, Arthur F. 1955. The Process of Government (Evanston).

[11]. Berghe, P.L. Vanden. 1981. The Ethnic Phenomenon (New York: Elsevier).

[12]. Bhargava, Rajeev. 1991. 'The Right to Culture' in K.N. Pannikar (ed.), Communalism in Indian History, Politics and Culture (Delhi: Manohar Publishers).

[13]. Brass, Paul R. 1991. Ethnicity and Nationalism (New Delhi: Sage Publications).

[14]. Brass, Paul R. 1974. Language, Religion and Politics in North India (London: Cambridge University Press).

[15]. Chakrabarty, Dipesh. 1995. 'Modernity and Ethnicity in India', EPW (Vol. 30: No. 52).

[16]. Chandhoke, Neera. 1999. 'A nation searching for a narrative in times of globalization', $E P W$ Vol. 35: No. 18).

[17]. Chatterjee, Partha. 1994. 'Secularism and Toleration', EPW (July 9).

[18]. Dahl, Robert A. 1989. Democracy and Its Critics (New Haven: Yale University Press).

[19]. Gupta, Dipankar. 2007. 'Citizens versus People', Sociology of Religion (Vol. 68: No. 1).

[20]. Gutmann, Amy. 1994. 'Introduction' in Multiculturalism: Examining the Politics of Recognition (Princeton: Princeton University Press).

[21]. Harrison, Selig S. 1960. India: The Most Dangerous Decades (Princeton: Princeton University Press).

[22]. Hasan, Zoya. 2003. 'Social Inequalities, Secularism and Minorities' in Mushirul Hasan (ed.), Will Secular India Survive?

[23]. Held, David. 1994. 'Democracy: From City-States to Cosmopolitan Order?' in The Polity Reader in Social Theory (Cambridge: Cambridge University Press).

[24]. Justino, Patricia and Julie Litchfield. 2003. Economic Exclusion and Discrimination (London: Minority Rights Group).

[25]. Kothari, Rajni. 1970. Politics in India (Boston: Little Brown).

[26]. Kothari, Rajni. 1989. Politics and the People (New Delhi: Ajanta Publications).

[27]. Kothari, Rajni. 1986. 'Fundamentalism not the essence of Hinduism', Illustrated Weekly of India (Dec. 7-13).

[28]. Lijphart, Arend. 1996. 'The Puzzle of Indian Democracy', The American Political Science Review (Vol. 90: No. 2).

[29]. Lijphart, Arend. 1979. 'Consociation and Federation: Conceptual and Empirical Links', Canadian Journal of Political Science (Vol. 12).

[30]. Lipset, Martin Seymour. 1960. Political Man: The Social Bases of Politics (Garden City).

[31]. Mahajan, Gurpreet. 1998. Identities and Rights (New Delhi: Oxford University Press).

[32]. Mahajan, G. Pai, Sudha and Jayal, N.G. 1994. 'State and New Liberal Agenda in India', EPW (Vol. 29: No. 19).

[33]. McGrane, Bernard. 1989. Beyond Anthropology (New York: Columbia University Press).

[34]. McGrane, Bernard. 1989. Beyond Anthropology: Society and the Other (New York: Columbia University Press).

[35]. Mill, J.S. 1958. Considerations on Representative Government (New York: Liberal Arts Press).

[36]. Mouffe, Chantal. 1990. 'Rawls: Political Philosophy without Politics' in David Rasmussen (ed.), Universalism vs. Communitarianism: Contemporary Debate in Ethics (Cambridge: Cambridge University Press).

[37]. Mullally, Siobhan. 2004. 'Feminism and Multicultural Dilemmas in India', Oxford Journal of Legal Studies (Vol. 24: No. 4).

[38]. Nandy, Ashis. 1988. 'The Politics of Secularism and the Recovery of Religious Tolerance', Alternatives (Vol. not found).

[39]. Nussbaum, M. 1999. Sex and Social Justice (Oxford: Oxford University Press).

[40]. Rajan, Nalini. 2002. Democracy and the Limits of Minority Rights (New Delhi: Sage Publications). 
[41]. Scott, J. 1998. 'Law, Legitimacy and the EC Governance: Prospects for "Partnership”, Journal of Common Market Studies (Vol. 36).

[42]. Subramanian, Narendra. 1999. 'Ethnicity and Pluralism', Canadian Journal of Political Science (Vol. 32: No. 4).

[43]. Taylor, Charles. 1992. 'Politics of Recognition' in Amy Gutmann (ed.), Multiculturalism and the Politics of Recognition (Princeton: Princeton University Press).

[44]. Truman, David B. 1951. The Governmental Process: Public Interests and Public Opinion (New York).

[45]. Tully, James. 1995. Strange Multiplicity: Constitutionalism in an Age of Diversity (Cambridge: Cambridge University Press).

[46]. Washbrook, David. 2010. 'Intimations of modernity in South India', South Asian History and Culture (Vol. 1: No. 1).

[47]. Weiner, Myron. 1989. The Indian Paradox (New Delhi: Sage Publications).

[48]. Weiner, Myron. 1968. 'Political Development in the Indian States' in State Politics in India (Princeton: Princeton University Press).

[49]. Young, Crawford. 1976. The Politics of Cultural Pluralism (Madison: University of Wisconsin Press). 